У симфоніях №№ 7 - 9 періоду сорокових років (відповідно, роки $1941,1943,1945)$ розгортається панорама оркестрових знахідок у галузі використання переважно виразних ресурсів бас-кларнета та кларнетапікколо.

3 симфоній 50-х років та початку шістдесятих (відповідно № $10-$ 1953 р., № 11 - 1957 р., № 12 - 1961 р.) стверджується новий тип розгорнутого оркестрового висловлювання композитора, а 3 ним i кларнетові соло починають змінюватися. Від активних учасників інструментального діалогу в оркестрі, група кларнетів переходить в нову якість носіїв розлогих відкритих соло монологічного типу, що й закріплюється у функціях кларнета у партитурах симфоній № 13 (1962 року) та № 15 - 1971 року.

\title{
Література:
}

1. Акопян Л.О. Дмитрий Шостакович: опыт феноменологии творчества. СПб.: изд-во «Дмитрий Буланин», 2004. 475 с.

2. Отчет аспиранта Ленинградской государственной консерватории Дмитрия Шостаковича: Архив ЛГК [без даты]. Шостакович Д. Д. Полное собрание сочинений в 42 томах. Том 01. М.: Музыка, 1987. С. 14.

DOI https://doi.org/10.30525/978-9934-26-004-9-81

\section{ПОПУЛЯРНА МУЗИЧНА КУЛЬТУРА УКРАЇНИ В ЕПОХУ ГЛОБАЛІЗАЦІЇ}

Борин О. В. аспірантка ДВНЗ «Прикарпатський наџіональний університет імені Василя Стефаника» м. Івано-Франківськ, Украӥна

Сучасна українська культура яскраво виражена розвитком популярної музичної культури. У період глобалізаційних процесів та соціокультурних змін з'являються нові культурні явища. Вивчення як позитивних, так і негативних впливів глобалізації на мистецькі процеси української національної культури займає важливе місце в сучасних культурологічних та мистецтвознавчих дослідженнях. 
Термін «глобалізаційна культура» з'явився наприкінці 80-х рр. XX ст. як відображення нової якості людини внаслідок прискорення інтеграції націй у світову систему, пов'язану 3 розширенням сучасних транспортних засобів та економічних зв'язків, формуванням транснаціональних корпорацій та впливом засобів масової інформації. Важливою проблемою у цих умовах є внутрішня мотивація людини, іiі самоідентифікація, що і є головним наслідком глобалізації. Як суспільне явище, культура пов'язана 3 простором, а окремі ії̈ структури та витвори функціонують на територіях, де проживають іï творці і споживачі. Культурна глобалізація характеризується зближенням культур різних націй, країн і призводить до поглинання національних надбань культури популярними зарубіжними, часткового їх зникнення, або перетворення на інтернаціональні, що можна розцінювати як втрату національної ідентичності [2, с. 13]. Особливо помітно вплив глобалізації проявляється у музичній культурі, що виражається в стрімкому поширенні світової популярної музичної культури в усіх країнах світу.

На думку Л. Каменецької, популярна вокальна музика утворює один 3 найважливіших пластів музичної культури нашого часу. Така музика має власний вокальний та інструментальний виконавський стиль, оригінальну, дещо специфічну мову тощо. Вокальна музика популярних жанрів детермінована різноманітними новоутвореннями, що значно збагачують іï, але суттєво не змінюють $[1$, с. 6]. «Популярна вокальна музика відрізняється жанрово-стильовою багатогранністю, тематичним розмаїттям. У процесі свого розвитку ці стилі та напрями впливали один на одного. Їх взаємопроникнення дало величезну кількість різновидів. До вокальної популярної музики ми відносимо такі основні напрями та стилі: джаз, рок, поп-музика, ритм-енд-блюз, хіп-хоп (реп), соул, диско, естрадна пісня, авторська (бардівська) пісня. Кожен стильовий напрям та стиль популярної вокальної музики має власну манеру подачі звуку і використання різних звукових ефектів» [1, с. 7].

Л. Каменецька визначає ознаки, що притаманні виконанню сучасної популярної вокальної музики: «емоційна насиченість, навіть дещо надмірна експресивність; імпровізаційність; ритмове розмаїття; виконання не тільки рідною, а й іноземними мовами; спів 3 використанням технічних засобів; спів, поєднаний 3 танцювальними рухами; використання різноманітних голосових ефектів; невимушеність поведінки на сцені; застосування світлових ефектів; використання незвичайних (дещо екстравагантних) сценічних костюмів; декораційне оформлення сцени тощо» $[1$, с. 8$]$. 
3 огляду на тенденцію об’єднання різних культур, водночас відбувається і взаємовплив різноманітних явищ музичного мистецтва у межах однієї національної культури, що у подальшому може стати ключовим елементом у процесі актуалізації національних культур. Одним 3 найголовніших складників культури народу завжди був фольклор. «Саме в усній народній творчості зберігались характерні риси етносу - обряди, вірування, особливості мови та інші прояви національної самобутності. Існування фольклору в XX-XXI ст. не тільки як окремої галузі музичної культури, а як складового компоненту музичних стилів та жанрів, які є найбільш поширеними серед широких верств населення, сприяє виникненню дослідницької зацікавленості в ньому, усвідомленню національної специфіки та його глибокого філософського значення» [4, с. 10].

Дослідниця В. Тормахова виділяє типи взаємодії фольклору 3 естрадною музикою, які, на іiі думку, можуть зацікавити українського слухача та посприяти популяризації української національної музичної культури. Відтак, вона виділяє наступні взаємозв'язки: «обробка народних пісень; цитування музично-фольклорного матеріалу; створення оригінальних композицій на фольклорній основі - інтонаціях, звукорядах, текстах, прийомах виконання; сплав національної манери виконання 3 інофольклорною (застосовується в джазі, поп-музиці)» [4, c. 10]. Взаємодія фольклору та естрадної музики характеризується використанням народних інструментів або автентичної манери гри, а також виконанням мелодійних ліній та багатоголосних шарів в автентичній фольклорно-співочій манері.

О. Шевченко вдало підкреслює, що «українська популярна музика одночасно $є$ музичним явищем, явищем суспільної свідомості i соціальним феноменом. Адже, за своєю природою вона призначена для масового сприйняття, а суспільство при цьому має потребу в такому мистецтві, яке може оперативно відгукуватися на його різноманітні та швидко змінювані потреби, зокрема, потребу у відпочинку, розвагах, спілкуванні з однолітками, звуковому оформленні побуту, де велике значення має синтез музики і слова, танцю, дії, сценічного оформлення» $[5$, c. 8$]$.

Загалом, тенденції розвитку популярної музичної культури України полягають у посиленні розвитку національної культури, іiї популяризацією та виходом на світовий музичний рівень. В. Малімон акцентує увагу на тому, що з метою актуалізації потужного культуро творчого потенціалу української нації державна культурна політика повинна враховувати наступні умови: «розвиток національної культурної 
самобутності має розгортатися у тісній взаємодії з європейськими та світовими культурними процесами; вітчизняні культурні індустрії як важливий засіб розвитку національної культури повинні сприяти розвитку міжкультурного обміну у напрямі «діалогу культур»; процес формування та реалізації державної культурної політики має не лише відповідати принципам культурної політики міжнародних організацій, а й враховувати власну специфіку культуро-, націє-, та державотворчих процесів; мають бути розроблені «альтернативні» підходи щодо протидії деструктивним процесам глобалізації; розвиток ринкового сектора культури, культурних індустрій у рамках національної культурної політики повинен грунтуватися на гуманістичному вимірі культури (як альтернативі «культури споживання»)» [3, с. 359].

Отже, процес культурної глобалізації є досить суперечливим. Він сприяє взаємопроникненню загальних світових культурних цінностей, які подаються як загальнозначимі в межах єдиного культурного простору, але водночас становить загрозу для розвитку національних культур, поширенні множинності, мозаїчності культур та ідентичностей. Тому саме рівнозначне співіснування глобалізаційної та національної культур, їхня взаємодія та розвиток у межах національної музичної культури можуть посприяти виникненню нових музичних напрямків, форм та виражень.

\section{Література:}

1. Каменецька Л. М. Формування культури виконання популярної вокальної музики у старшокласників: автореф. дис. ... канд. пед. наук: 13.00.02 / Нац. пед. ун-т ім. М. П. Драгоманова. Київ, 2009. 23 с.

2. Красівський О. Я. Глобалізація та ідентичність національної культури. Ефективність державного управління. 2017. Вип. 4. С. 13-21.

3. Малімон В. І. Проблеми державної культурної політики в Україні на сучасному етапі розвитку суспільства. Університетські наукові записки. 2008. № 4. С. 355-360.

4. Тормахова В. М. Українська естрадна музика i фольклор: взаємопроникнення і синтез: автореф. дис. ... канд. мистецтвознав.: 17.00.03 / Нац. муз. акад. України ім. П. І. Чайковського. Київ, 2007. 17 с.

5. Українська популярна музика: витоки та проблематика (1920 1990 рр.): автореф. дис. ... канд. мистецтвознав.: 26.00.01 / Київ. нац. ун-т культури і мистецтв. Київ, 2010. 20 с. 